\title{
Review Article on Queer Studies
}

\author{
Rohit K Dasgupta, University of Southampton
}


Straight Girls and Queer Guys: The Heteromedia gaze in Film and Television, Christopher Pullen, 2016 Edinburgh: Edinburgh University Press, ISBN 9780748694846

Same Sex desire in Indian Culture: Representations in Literature and Film 1970-2015, Oliver Ross, 2016 London: Palgrave Macmillan, ISBN 9781137570758

Queer Lovers and Hateful Others: Regenerating Violent Times and Places, Jin Haritaworn, 2015, London: Pluto Press, ISBN 9780745330617

Entering Transmasculinity: The inevitability of Discourse, Matthew Heinz, 2016 Bristol: Intellect, ISBN 9781783205684

Received May 19, 2016; Accepted July 28, 2016; Published August 18, 2016

Scholarship on queer studies has grown exponentially in the last two decades ever since it emerged in the 1990's. They have all contributed significantly to various cross-disciplinary fields and regional studies. In this short piece I offer a review of four recent books which have taken queer studies to new forms of critical advancement. All four books offer diverse forms of disciplinary and theoretical grounding and different methodological approaches towards studying queer texts and cultures.

Pullen's book Straight Girls and Queer Guys explores the friendship that exists between straight girls and queer guys in film and television culture since 1948 until the present time. According to Pullen these 'unlikely coupling' offers an awkward subtext which also offers reference to wider notions of homosociality (3). In chapter 1 the author discusses the emergence of this 'coupling' through a discussion of films by Doris Day, Rock Hudson and Tony Randall. This chapter helps develop the author's conceptual framework of the gaze. He argues that in the case of these early films the gaze is less about looking and finding and more about sensing. Whist

(c) AesthetixMS 2016. This Open Access article is published under a Creative Commons Attribution Non-Commercial 4.0 International License (http://creativecommons.org/licenses/by-nc/4.o/), which permits non-commercial re-use, distribution, and reproduction in any medium, provided the original work is properly cited. For citation use the DOI. For commercial re-use, please contact editor@rupkatha.com. 
these films had no explicit representation of queer desire, through adopting covert reading alongside the life narratives of these stars audience is able to sense the coupling and queer presence.

The author continues this exploration in chapter 3 where spectatorship and the star identity is more centrally examined through films such as the British Carry On Series and the character of Kenneth Williams and other comic films employing the 'gay best friend' character. Pullen discusses how Williams character evolved over time where his campness was intimately connected in the ways in which he was made to interact with other female charcters. In the series he was often presented in situations where he has to reject the sexual advances of female characters in awkward ways where he is represented in collusion with the female characters in 'explicit queer contexts' (73). Pullen ends the chapter by arguing that characters such as Williams is not identified only through feminisation but rather the straight girl is used as a frame to mask and masquerade the queerness.

In the final three chapters Pullen looks at representations from television and documentary examining youth culture texts such as GBF and Glee. Pullen's book is an important intervention into queer screen culture. In presenting the heteromedia gaze, Pullen offers a reading of how the coupling of straight girls and queer men resist the dominant desiring gaze with a sense of transgression and rebellion, thus offering not only new ways of seeing and reading these texts but also revealing the incomplete continuum of such reading.

The second book Oliver Ross's Same Sex desire in Indian Culture explores the representation of same sex desire in Indian literature and film texts since the 1970's to 2015. Ross argues that whilst his study adds to the current (limited) scholarship on queer studies in India, this work also attempts to study the text rather than the context, which much of the current scholarship has done. He further name calls a few publications to state that all of these have privileged an all-embracing perspective over the close analysis of texts, something he has attempted in this book. The chapters look at a variety of literary and cinematic texts. Whilst almost all the texts discussed in this book have been a part of previous academic studies, Ross does bring a fresh breath of analyses to them. Interestingly Ross describes his aversion to the term queer because of its origin as a 'political metaphor without a fixed referent'. Whilst it is not the purpose of this review to go into detail about the limitations of such a position, Paul Boyce's(2012) work on terminologies might be a useful detour for the author.

In chapter 1 Ross establishes a dialogue between Deepa Mehta's celebrated film Fire and Ligy Pullappally's Sancharram, to show how female female desire is expressed and sanctioned through contrasting attitudes. There is some very strong analysis here and Ross makes a good point about how Pullappally's film draws upon Malayali and euro-American tradition to 'achieve its validity and comprehensibility' (62). The author could have also benefited from Gayatri Gopinath's (2007) exploration of the same film through a critical regionalism lens. My favourite remains his final chapter on My Brother Nikhil, 68 Pages and Thang. The author rightly points out that these films are excellent texts of the sympathetic representations of homosexuality in Indian cinema. Also important about these texts are the ways in which it foregrounds HIV/AIDS to challenge the stigma of sexual health. Unlike America and the New Queer Cinema movement which grew to combat the stigma of HIV/AIDS, India never had the moment, yet these films are key texts to study the transition of the sidelined gay character of the 1990's to full fledged nuanced characters of these films (as the author importantly points out).

Jin Haritaworn's Queer Lovers and Hateful Others is a fantastic study of queer space and queer subjects through three interconnected themes of love, hate and nostalgia. Haritaworn's 
book is primarily based on ethnography and interviews that the author did with 15 queers of colour in Berlin, Germany. Haritaworn begins by describing the 'birth' of the homophobic Muslim, ('a new folk devil') by the State in areas that are already marked by racism, gentrification and neoliberal restructuring (3) thus ascribing homophobia as a racialised incitement. The author proposes the term 'queer regeneration' to critically explore how certain queer bodies are rendered legible whilst others rarely gain the status of visibility. The book traces these shifts to ask how racialised and gendered bodies are carved out through larger bio-political and neo-political questions of who gets to live and who die (4). In the first chapter Haritaworn maps our these queer spaces, arguing that it is important to critically map transgressive and homonormative geographies as intersecting rather than contradictory sites of queer making (31).

Chapter 2 titled 'Love' looks at how queer images of affection- 'queer kisses', now proliferate former spaces of degeneration where they share space with a discourse of racialised others (Turkish youth) as being homophobic. The author argues that whilst trans people are claimed the 'innocent others' of homonationalism (109), at the same time, the queer community is still unwilling to consider racialised trans lives as vulnerable or queer people of colour as 'coalition partners' (133). In the next chapter, the author furthers this argument by exploring the birth of this 'hateful other'. Haritaworn argues that hate has an individualised and depoliticising tendency by sticking to racialised bodies that do not fit neoliberal subjectivity (141). Haritaworn thus questions again- within sexual citizenship frameworks who has to 'die' for some to live? In the final short chapter on queer nostalgia, Haritaworn draws some excellent observations on remembering hate and queer memorialisation. The author argues that these acts of remembrance do more than merely grieve; rather it becomes an active investment in 'murderous times and places' that the queer subject tries to overcome. This short but most interesting chapter opens up some interesting conversations around the politics of remembrance and the complicity of homophobia with racialised homophobia. I hoped that the author would continue exploring some of these concerns but stops short and herein lay my only criticism of this otherwise excellent book.

The final book under consideration is Matthew Heinz's Entering Transmasculinity. Similar to the other three this is a good book and makes a timely intervention into the study of trans* identities. There are 4 chapters looking at different aspects of trans* lives- the first two chapters 'the transmasculine patient' and 'norming abnormality' explores the medicalised discourse around trans and the ways through which trans lives have been co-opted within the mainstream. The final 2 chapters- 'finding one's male self and 'a man's man' captures the everyday transmasculine experience of individuals and the various ways through which they identify and perceive themselves. Through an examination of how transmasculine people self identify and are represented within images and texts, Heinz argues that the dominant mainstream media images are not often representative of trans* people themselves. Heinz also argues about the potential of language- both for its empowering as well as restricting possibilities.

Perhaps as with the other three book's Heinz's exploration is nuanced. He notes that the unidimensional image of trans* lives is incorrect and belie the complexity attached to them. He speaks of the contradictions that exist through trans* lives want to be part of the 'normative' mainstream discourse but at the same time also maintain its transgressive potential. Through a synthesis of these diverging areas and looking at the unconstrained and (often) liberating potential of the identity, the author dismisses some of the homogenising ways through which trans* lives have been discussed. Heinz instead advocates studying trans* lives through their own 
narratives and stories. All four books discussed in this review make invaluable contribution to queer studies and recommend them highly to the readers of this journal.

\section{References}

Boyce, P. (2012) 'The Ambivalent Sexual Subject,' in Aggleton, P., Boyce, P., Moore, H.L., and Parker, R. (eds.) Understanding Global Sexualities. London: Routledge, pp. 75-88.

Gopinath, G. (2007) "Queer Regions: Locating Lesbians in Sancharram" in G.E. Haggerty and M. McGarry (eds.) A Guide to Lesbian, Gay, Bisexual, Transgender and Queer Studies. London: Wiley Blackwell, pp. 341-354 